\title{
SALINITY RESISTANCE AND ABILITY OF N2-FIXING RHIZOBACTERIA ISOLATES TO IMPROVE RICE SEEDLING GROWTH UNDER SALINITY STRESS
}

\author{
Roby Ibnu Syarifain ${ }^{1}$, Reginawanti Hindersah ${ }^{2}$, Mieke Rochimi Setiawati ${ }^{2}$ and Tualar Simarmata ${ }^{2}$ \\ ${ }^{1}$ Padjadjaran University, Faculty of Agriculture, Soil Science Magister Program,Bandung Sumedang street KM 21, \\ Jatinangor 45363 \\ ${ }^{2}$ Padjadjaran University, Faculty of Agriculture, Department of Soil Science and Land Resource ,Bandung \\ Sumedang street KM 21, Jatinangor 45363 \\ https://doi.org/10.35410/IJAEB.2022.5707
}

\begin{abstract}
Salinity is the main limiting factor that inhibits the growth of rice plants significantly. N2-Fixing Rhizobacteria halotolerant able to increase the growth of cave rice plants to support plant productivity. This study was conducted to test PA and KP2 isolates to grow and increase Inpari rice plant growth at salinity stress $(0,4,8$, and $12 \mathrm{dSm}-1)$. This study used GT (Growth time) with three replications to identify isolates growth ability on salinity stress as first stages. The second stage was to determine isolates ability to improve rice seedling growth under salinity stress using a randomized block design with twelve treatments and three replications. The result showed that all isolate could grow and tolerate salinity stress up to $12 \mathrm{dSm}-1$ and growth faster under salinity stress after 48 hours from inoculation. PA isolate grew $42.92 \%$ while KP2 isolate was $57.80 \%$ faster at $12 \mathrm{dSm}-1$ compared to non-saline condition. The result also showed that KP2 isolate give the best performance at $4 \mathrm{dSm}-1$ significantly increasing plant height $50.45 \%$, plant height $183.88 \%$ compare to without inoculation on the same level salinity. Therefore, that ideal salinity for KP2 isolates to improve rice seedling growth under salinity stress was $4 \mathrm{dSm}-1$.
\end{abstract}

Keywords: Growth time, Inpari 79 Unsoed, N2-fixing rihizobacteria, salinity resistance .

\section{INTRODUCTION}

Land conversion and climate change have reduced land area and rice productivity in Indonesia. This is in accordance with [1] which shows that the area of rice land decreased from 11,377,934 ha in 2018 to $10,677,887$ ha in 2019 and rice productivity decreased from $5.2 \mathrm{t} \mathrm{ha}^{-1}$ in 2018 to 5 $.1 \mathrm{t} \mathrm{ha}^{-1}$ in 2019. The declining land area has resulted in the need for extensification efforts by utilizing sub-optimal land such as coastal areas that have high salinity. Climate change is causing the ice in the north and south poles to melt, resulting in rising sea levels. Rising sea levels increase seawater intrusion up to $20 \mathrm{~km}$ from the coastline which can be a serious problem, especially in Java, because Java Island is a national rice barn with an area of irrigated land of 3.3 million ha (42.5\%) of the irrigated land area national, and 407,594 ha on the coast [2], [3].

High soil salinity damages soil structure, reduces aeration, permeability, nitrogen availability, and increases soil osmotic potential, causing physiological drought in plants [4]. In saline ecosystems, nitrogen deficiency generally occurs as a result of inhibition of the nitrogen cycle by microbes because high salt concentrations can result in plasmolysis in saline intolerant microbes [5]. The high accumulation of $\mathrm{Na}^{+}$and $\mathrm{Cl}^{-}$in the soil also reduces the availability of nutrients such as $\mathrm{K}^{+}, \mathrm{Ca}^{2+}, \mathrm{Fe}^{2+}$, and $\mathrm{Mg}^{2+}$ due to competition with $\mathrm{Na}^{+}$and $\mathrm{Cl}^{-}$in the process of nutrient 
Vol. 07, No. 01; 2022

ISSN: $2456-8643$

uptake by plant roots [6]. This problem is exacerbated by the characteristics of rice plants which are generally relatively sensitive to salinity stress with a threshold that causes a decrease in yield between $1.9-3 \mathrm{dSm}^{-1}$ and if the EC is above $3 \mathrm{dSm}^{-1}$ it will cause a decrease in the yield of $12 \%$ for every $1 \mathrm{dSm}^{-1}$. Therefore, under stress conditions of $6 \mathrm{dSm}^{-1}$ the decrease in rice yield reached 50\% [7]. Therefore, efforts are needed to overcome the deficiency of $\mathrm{N}$ in saline soils and increase the tolerance of rice plants to increased salinity. Under salinity stress, the concentration of the solution outside the roots was higher than inside the plant roots due to the presence of excess $\mathrm{Na}^{+}$and $\mathrm{Cl}^{-}$ions, resulting in a decreased ability of the roots to absorb water due to osmotic stress [8]. A decrease in the rate of water uptake will reduce the rate of photosynthesis and increase respiration so that the sugar produced by photosynthesis cannot be used to support plant growth [9].

Rhizobacteria that live in the rhizosphere have the ability as a biofertilizer such as $\mathrm{N}_{2}$-fixing from the atmosphere catalyzed by the nitrogenase enzyme. Biological nitrogen fixation is important because nitrogen is a necessary macronutrient for plant growth and is abundant in the atmosphere, but cannot be absorbed by plants. This is because atmospheric nitrogen is in the form of $\mathrm{N}_{2}$ in the atmosphere. Therefore, atmospheric nitrogen needs to be converted into ammonia by rhizobacteria through nitrogen fixation. Rhizobacteria that have the ability to fix $\mathrm{N}_{2}$ include Rhizobium trifolii, Bradyrhizobium sp., Sinorhizobium meliloti, Azotobacter agilis, Azotobacter chroococcum, Azotobacter vinelandii and Klebsiella pneumoniae [10].

Rhizobacteria isolated from saline ecosystems have the ability in nitrogen fixation. [4] stated that rhizobacteria such as Azotobacter sp. isolated from saline soil ecosystems had the ability to increase plant height and root length of rice. This is because these bacteria have the ability to convert free nitrogen in the atmosphere into ammonia needed by plants [11]. The research showed that Pseudomonas stutzeri ISE12 has the ability to increase plant resistance to salinity stress, because it has the ability to reduce stress due to salinity stress which is indicated by a decrease in proline concentration in plants (increases with salinity to balance osmotic pressure) thereby significantly increasing the number of leaves, dry weight $(50,150$, and $300 \mathrm{mM} \mathrm{NaCl})$, and significantly reduced the proline content in plant roots at $300 \mathrm{mM} \mathrm{NaCl}$ [12]. Research by Habib on rice plants in saline soils showed that Rhizobacteria could significantly improve the performance of rice plants in saline soils compared to plants that were not inoculated by $\mathrm{N}_{2-}$ fixing microbes Bacillus sp. and Citrobacter sp [13].

\section{MATERIAL AND METHODS}

The research was carried out in July-August 2021 at the Soil Biology Laboratory and Greenhouse Faculty of Agriculture, Padjadjaran University. Isolates that were used came from rice plant rhizosphere from Cilamaya, Karawang, West Java, Indonesia. This study used GT (Growth time) with three replications to identify isolates (PA and KP2) growth ability on various salinity stress $\left(0,4,8\right.$, and $\left.12 \mathrm{dSm}^{-1}\right)$ as first stages. The second stage was to determine isolates (PA and KP2) ability to improve rice seedling growth under various salinity stress $(0,4,8$, and $12 \mathrm{dSm}^{-1}$ ) using a randomized block design with three replications.

\subsection{Materials}

In this research, there are several tools and materials used. Salinity resistance assay used Ashby mannitol consist of ( $10 \mathrm{~g}$ mannitol, $0.2 \mathrm{~g} \mathrm{~K}_{2} \mathrm{HPO}_{4}, 0.2 \mathrm{~g} \mathrm{MgSO}_{4} . \mathrm{H}_{2} \mathrm{O}, 0.1 \mathrm{~g} \mathrm{CaSO}_{4} .2 \mathrm{H}_{2} \mathrm{O}$, and 5 
$\left.\mathrm{g} \mathrm{CaCO}_{3}\right)$ per litre, $\mathrm{NaCl}$, petri dish, erlemeyer $(100$ and $250 \mathrm{~mL})$, micropipet $(100 \mu \mathrm{L}$ and $8000 \mu \mathrm{L})$ with microtips, test tube $10 \mathrm{~mL}$, Laminar air flow, Autoclaf. Bioassay used Inpari Unsoed 79 Agritan seed, parchment paper, $\mathrm{NaCl}$, test tube $100 \mathrm{~mL}$, venier calipers, measuring tube, label and Fahraeus media nitrogen free consist of $\left(0,132 \mathrm{~g} \mathrm{CaCl}_{2}, 0,12 \mathrm{~g} \mathrm{MgSO}_{4} .7 \mathrm{H}_{2} \mathrm{O}, 0,1\right.$ g $\mathrm{KH}_{2} \mathrm{PO}_{4}, 0,075 \mathrm{~g} \mathrm{Na}_{2} \mathrm{HPO}_{4} .2 \mathrm{H}_{2} \mathrm{O}, 5 \mathrm{mg} \mathrm{Fe}$-sitrat, dan $0,07 \mathrm{~g} \mathrm{MnCl}_{2} .4 \mathrm{H}_{2} \mathrm{O}, \mathrm{CuSO}_{4} .5 \mathrm{H}_{2} \mathrm{O}$, $\mathrm{ZnCl}_{2}, \mathrm{H}_{3} \mathrm{BO}_{3}$, dan $\mathrm{Na}_{2} \mathrm{MoO}_{4} .2 \mathrm{H}_{2} \mathrm{O}$ ) per litre [14].

\subsection{Salinity Resistance Assay}

Determination of salinity resistance of rhizobacteria isolates (PA, and KP2) using Ashby mannitol liquid media with salinities of $0,4,8$, and $12 \mathrm{dSm}-1$. Calculation of the growth of isolates using the direct calculation method with several stages. Ashby mannitol media (10 g mannitol, $0.2 \mathrm{~g} \mathrm{~K}_{2} \mathrm{HPO}_{4}, 0.2 \mathrm{~g} \mathrm{MgSO}_{4} . \mathrm{H}_{2} \mathrm{O}, 0.1 \mathrm{~g} \mathrm{CaSO}_{4} .2 \mathrm{H}_{2} \mathrm{O}$, and $5 \mathrm{~g} \mathrm{CaCO}_{3}$ ) per litre, made up to $50 \mathrm{ml}$ for each treatment [15]. The addition of $\mathrm{NaCl}$ salt was carried out at the same time as mixing the media material with a weight of $0.7913 \mathrm{~g} \mathrm{~L}^{-1}$ for a salinity of $4 \mathrm{dSm}^{-1}, 1.9113 \mathrm{~g} \mathrm{~L}^{-1}$ for a salinity of $8 \mathrm{dSm}^{-1}$, and $4.5469 \mathrm{~g} \mathrm{~L}^{-1}$ for a salinity $12 \mathrm{dSm}^{-1}$. Weight of salt addition and media formula Ashby Mannitol was obtained from the calculation of the standard curve of media salinity. Pure cultures of rhizobacteria isolates that had been incubated for 3 days were inoculated as much as $10 \%$ of the volume of the medium (by suspending the culture in $5 \mathrm{~mL}$ of sterile $0.85 \% \mathrm{NaCl}$ Solutions) into $50 \mathrm{~mL}$ of Ashby mannitol which was placed in a $250 \mathrm{~mL}$ Erlenmeyer for each treatment and stored in a gyratory shaker. at $115 \mathrm{rpm}$ at room temperature 23-26 ${ }^{\mathrm{O}} \mathrm{C}$ [16]. Measurements were made immediately after inoculation to determine the initial population and every 24 hours for 4 days after inoculation with a dilution factor at intervals of $10^{-4}$ to $10^{-7}$ using the Total Plate Count method and calculated by the following formula:

$G T=\frac{t}{n}$

$n=\frac{\left(\log n_{t}-\log n_{o}\right)}{\log g_{2}}$

Annotation:

GT : Generation time at logarithmic phase

n : generation number

$\mathrm{n}_{\mathrm{t}} \quad:$ Cell density at sampling time $\mathrm{t}$

$\mathrm{n}_{0} \quad$ : cell density at treatment time

$\mathrm{t} \quad$ : time (hour) between sampling time

\subsection{Biological Assay}

The $\mathrm{N}_{2}$-fixing rhizobacteria bioassay was carried out with Fahraeus media nitrogen free $((0,132 \mathrm{~g}$ $\mathrm{CaCl}_{2}, 0,12 \mathrm{~g} \mathrm{MgSO}_{4} .7 \mathrm{H}_{2} \mathrm{O}, 0,1 \mathrm{~g} \mathrm{KH}_{2} \mathrm{PO}_{4}, 0,075 \mathrm{~g} \mathrm{Na}_{2} \mathrm{HPO}_{4} .2 \mathrm{H}_{2} \mathrm{O}, 5 \mathrm{mg}$ Fe-sitrat, dan 0,07 $\mathrm{g}$ $\mathrm{MnCl}_{2} .4 \mathrm{H}_{2} \mathrm{O}, \mathrm{CuSO}_{4} .5 \mathrm{H}_{2} \mathrm{O}, \mathrm{ZnCl}_{2}, \mathrm{H}_{3} \mathrm{BO}_{3}$, dan $\mathrm{Na}_{2} \mathrm{MoO}_{4} .2 \mathrm{H}_{2} \mathrm{O}$ ) per litre [14]. The media was then sterilized using an autoclave at $121{ }^{\circ} \mathrm{C}$ for 15 minutes at a pressure of $1 \mathrm{~atm}$. The addition of salt was carried out during the media making process by adding $\mathrm{NaCl}$ as much as $2.380 \mathrm{~g} \mathrm{~L}^{-1}$ for a salinity of $4 \mathrm{dSm}^{-1}, 5.050 \mathrm{~g} \mathrm{~L}^{-1}$ for a salinity of $8 \mathrm{dSm}^{-1}, 7.721 \mathrm{~g} \mathrm{~L}^{-1}$ for a salinity of $12 \mathrm{dSm}^{-1}$. Biological tests were carried out by using a $100 \mathrm{~mL}$ test tube filled with $90 \mathrm{ml}$ of saline liquid Fahraeus media and adding a liquid culture of isolate with an inoculation age of 72 hours on nonsaline Ashby mannitol media (10 g mannitol, $0.2 \mathrm{~g} \mathrm{~K}_{2} \mathrm{HPO}_{4}, 0.2 \mathrm{~g} \mathrm{MgSO}_{4} . \mathrm{H}_{2} \mathrm{O}, 0.1 \mathrm{~g}$ 
$\mathrm{CaSO}_{4} .2 \mathrm{H}_{2} \mathrm{O}$, and $5 \mathrm{~g} \mathrm{CaCO}_{3}$ ). Observations were made every seven days for $21 \mathrm{DAI}$ (Day after Inoculation) on variables such as root length, plant height, number of leaves, while observations of dry weight were carried out on day 28.

The inoculation of rhizobacteria in rice plants was carried out in several stages. Inpari Unsoed 79 Agritan was chosen because it belongs to the salinity tolerant variety [17]. Rice seeds were sterilized by immersion using $0.2 \% \mathrm{HgCl}_{2}$ for 2 minutes and followed by sterilization with $70 \%$ alcohol for 2 minutes and rinsed with sterile distilled water and then germinated. The sown rice seeds were soaked in distilled water for 24 hours at room temperature to break seed dormancy and stimulate growth hormone $25{ }^{\circ} \mathrm{C}$ [18]. Each tube containing $90 \mathrm{~mL}$ of Fahraeus media was given $10 \mathrm{~mL}$ of liquid culture of halotolerant $\mathrm{N}_{2}$-fixing rhizobacteria isolates at $10^{9} \mathrm{CFUmL}^{-1}$ and then planted in Fahraeus media that had been prepared previously with one rice plant for 100 $\mathrm{mL}$ test tubes. Maintenance is carried out in the form of adding Fahraeus saline media according to treatment if needed until it reaches the $100 \mathrm{~mL}$ limit that has been made in the test tube. After that, each treatment was placed in the greenhouse of the Soil Biology Laboratory, Padjadjaran University to be observed (number of leaves, plant height, and root length, every seven days until the plant was 21 days after inoculation [4].

\subsection{Data Analysis}

This research has two stages. First stage was carried out with descriptive quantitative design using GT (generation time) calculation from three replication data to asses rhizobacteria salinity resistance. Second stage used randomized block design with three replications then data was analyzed using SPSS 25 continued with Tukey's range test $\mathrm{p} \leq 0.01$.

\section{RESULT AND DISCUSSION}

\subsection{Salinity Resistance Assay}

Microbial salinity resistance is the ability of microbes to continue to grow and divide cells in an environment that has abiotic stress in the form of excess salt content. Resistance describes the ability of microbes to avoid structural changes in the community when stress occurs, both abiotic and biotic biotik [19]. Salinity resistance is one of the characters that need to be considered in the selection of $\mathrm{N}_{2}$-fixing rhizobacteria isolates to support the growth of rice plants in a saline environment because if the selected isolates do not have resistance to salinity, the proliferation of isolates will not be optimal, which has an impact on the carrying capacity that is less than optimal. One method to determine the resistance of $\mathrm{N}_{2}$-fixing rhizobacteria isolates is to perform a resistance test on $\mathrm{N}$-free media such as Ashby mannitol [15] which is treated with the addition of salt in the form of $\mathrm{NaCl}$ at various levels in $\mathrm{dSm}^{-1}$ units as shown in Table 1

Table 1: $\mathrm{N}_{2}$-fixing rizobacteria growth at various salinity

\begin{tabular}{|c|c|c|c|c|c|c|}
\hline \multirow[t]{2}{*}{ Isolates } & \multicolumn{5}{|c|}{$\mathrm{N}_{2}$-fixing rizobacteria population $\left(10^{6} \mathrm{CFU} \mathrm{mL}^{-1}\right)$} & \multirow{2}{*}{$\begin{array}{l}\text { Growth Time } \\
\text { at logarithmic } \\
\text { phase }\end{array}$} \\
\hline & $\begin{array}{l}\text { Salinity } \\
\text { levels } \\
\left(\mathrm{dSm}^{-1}\right)\end{array}$ & 0 hour & 24 hours & 48 hours & 72 hours & \\
\hline
\end{tabular}


Vol. 07, No. 01; 2022

ISSN: $2456-8643$

\begin{tabular}{|lllllll|}
\hline PA & 0 & 981 & 2,920 & 13,500 & 12,800 & 10.95 \\
PA & 4 & 169 & 9.7 & 208 & 152 & 5.39 \\
PA & 8 & 167 & 13.8 & 134 & 151 & 7.33 \\
PA & 12 & 131 & 18.3 & 269 & 137 & 6.25 \\
\hline KP2 & 0 & 573 & 6,160 & 14,900 & 14,500 & 18.91 \\
KP2 & 4 & 238 & 15.8 & 167 & 139 & 6.94 \\
KP2 & 8 & 128 & 15.9 & 125 & 179 & 8.26 \\
KP2 & 12 & 127 & 14.6 & 125 & 129 & 7.98 \\
\hline
\end{tabular}

Data were obtained from three replication

Table 1 showed that increasing salt content decreases the GT (Generation time) or the time required to duplicate two isolates of halotolerant $\mathrm{N}_{2}$-fixing rhizobacteria in the logarithmic phase. It can be seen that in the first 24 hours there was a decrease in the population of rhizobacteria in saline conditions, whereas in non-saline conditions the bacteria did not experience a population decline. Population decline is thought to be an adaptation phase for inoculants on saline media. In this phase the inoculant cells adapt to salinity stress conditions in the form of excess $\mathrm{Na}^{+}$and $\mathrm{Cl}^{-}$ions in the solution which causes an increase in solution potential because the solution outside the cell is more concentrated than inside the bacterial cell, resulting in osmotic stress [20]. then, the cell density of rhizobacteria in various salinity media increased at 48 hours. PA and KP2 isolates showed the increase of GT value due to salinity increase. This condition showed that isolate has adapted to salinity and able to grow faster compared to nonsaline condition. Visual observation showed that there was size reduction in colony, but there was more colonies at petri dish in saline condition compared to non-saline condition based on total plate counting. Salinity stress on microbes induces the production of secondary metabolites such as EPS to stabilize the solution potential because EPS has the function of binding cations such as $\mathrm{Na}^{+}$in $\mathrm{NaCl}$ and reducing bioavailability, therefore microbe could growth after adapting under stress conditions [19].

\subsection{Bioassay on Inpari Rice in Various Salinity}

\subsubsection{Effect $\mathbf{N}_{2}$-Fixing Rhizobacteria on Root Length}

The average root length used in the bioassay of rice plants was $37.67 \mathrm{~mm}$ and observations were made every 7 DAI (day of inoculation) to 21 DAI. This observation aims to determine effect $\mathrm{N}_{2-}$ fixing rhizobacteria on root growth of Inpari Unsoed 79 at various salinities as showed at Table 2 . 
Table 2: Effect of $\mathrm{N}_{2}$-fixing rizobacteria on Inpari rice root length 7-21 DAI at various salinity

\begin{tabular}{|llll|}
\hline Treatment & Root length $(\mathrm{mm})$ & & \\
& $7 \mathrm{DAI}$ & $14 \mathrm{DAI}$ & $21 \mathrm{DAI}$ \\
\hline $\mathrm{Cb} 0$ & $78.70 \mathrm{c}$ & $108.17 \mathrm{f}$ & $122.50 \mathrm{e}$ \\
$\mathrm{Cb} 1$ & $42,03 \mathrm{ab}$ & $71.27 \mathrm{bcd}$ & $79.03 \mathrm{~cd}$ \\
$\mathrm{Cb} 2$ & $35,30 \mathrm{a}$ & $41.10 \mathrm{a}$ & $41.77 \mathrm{a}$ \\
$\mathrm{Cb} 3$ & $40.60 \mathrm{ab}$ & $43.47 \mathrm{a}$ & $44.73 \mathrm{ab}$ \\
PAb0 & $49.70 \mathrm{ab}$ & $72.37 \mathrm{bcde}$ & $81.17 \mathrm{~cd}$ \\
PAb1 & $54,03 \mathrm{ab}$ & $88.73 \mathrm{def}$ & $103.40 \mathrm{de}$ \\
PAb2 & $38.87 \mathrm{ab}$ & $53.13 \mathrm{ab}$ & $56.57 \mathrm{abc}$ \\
PAb3 & $53,67 \mathrm{ab}$ & $59.17 \mathrm{abc}$ & $60.93 \mathrm{abc}$ \\
KP2b0 & $52.83 \mathrm{ab}$ & $82.60 \mathrm{cde}$ & $107.43 \mathrm{de}$ \\
KP2b1 & $60,27 \mathrm{ab}$ & $97.43 \mathrm{ef}$ & $118.90 \mathrm{e}$ \\
KP2b2 & $44,87 \mathrm{ab}$ & $69.30 \mathrm{bcd}$ & $73.03 \mathrm{bc}$ \\
KP2b3 & $53,67 \mathrm{ab}$ & $58.33 \mathrm{abc}$ & $62.63 \mathrm{abc}$ \\
\hline
\end{tabular}

Different letters over bar of indicates significant difference in treatment according to Tukey's multiple range test $\mathrm{p} \leq 0.01), \mathrm{C}$ (control), PA isolates, $\mathrm{KP} 2$ isolates, $\mathrm{b} 0\left(0 \mathrm{dsm}^{-1}\right), \mathrm{b} 1\left(4 \mathrm{dSm}^{-1}\right), \mathrm{b} 2$ $\left(8 \mathrm{dSm}^{-1}\right), \mathrm{b} 3\left(12 \mathrm{dSm}^{-1}\right)$

Table 2 showed that root growth KP2 at salinity level $4 \mathrm{dSm}^{-1}$ has the nog significant different with control at non-saline condition. This result showed that, inoculation $\mathrm{N}_{2}$-fixing rhizobacteria could improve root growth at 21 DAI in $4 \mathrm{dSm}^{-1}$ salinity level. The roots growth were varied from first week to third weeks. At first week control without salinity treatment has the highest value of root length, but at 14 DAI the conditions was changed, showed with there is no significant different between control without salinity which has root length $108.17 \mathrm{~mm}$ compared to isolate $\mathrm{KP} 2$ at $4 \mathrm{dSm}^{-1}$ salinity level which has root length $97.43 \mathrm{~mm}$. the trend at control showed that the increase of salinity decrease rooth length. Salinity stress changes physiological and metabolic processes that are influenced by severity and duration so that it could inhibit plant growth [21]-[24]. Excess $\mathrm{Na}^{+}$in the growing medium reduces the uptake of $\mathrm{K}^{+}$by the roots. This is because potassium and $\mathrm{Na}$ have the same transport mechanism, namely the $\mathrm{K}+$ transporter which consists of genes and proteins such as the HKT (histidine kinase transporter) and the NHX $\left(\mathrm{Na}^{+} / \mathrm{H}^{+}\right.$antiporter) which functions to remove excess $\mathrm{Na}^{+}$into the vacuole from the planting medium into the plant [25]. In the early stages of salinity stress, the process that inhibits plant growth is reverse osmosis followed by ion poisoning [21], [22]. During the initial phase of salinity stress, root absorption capacity decreases and water loss from leaves increases as a result of osmotic stress and excess salt accumulation in the growing media and plant tissues, so it can be categorized as hyperosmotic stress. Osmotic stress in the early days of salinity stress causes physiological changes such as membrane disturbances, nutrient imbalances, weakening of Reactive oxygen species (ROS) detoxification, decreased photosynthetic activity, and stomata opening [22], [26]. Salinity stress also causes hyper-ionic stress due to excess accumulation of $\mathrm{Na}^{+}$and $\mathrm{Cl}^{-}$ions in plant tissues that are in direct contact with growing media with high salt concentrations. Excess $\mathrm{Na}^{+}$and $\mathrm{Cl}^{-}$in plant tissue disrupts physiological processes such as 
inhibition of $\mathrm{K}^{+}$ion absorption which inhibits plant growth and development and causes plant death [21].

\subsubsection{Effect N-Fixing Rhizobacteria on Plant Height}

The average plant height used in the rice bioassay was $8.87 \mathrm{~mm}$ and observations were made every 7 DAI to 21 DAI. This observation aims to determine one of the growth components of Inpari Unsoed 79 rice plants at various salinities and BFHNR inoculation treatments as shown in Table 3.

Table 3: Effect of $\mathrm{N}_{2}$-fixing rizobacteria on Inpari rice plant height 7-21 DAI at various salinity

\begin{tabular}{|llll|}
\hline Treatment & Plant height $(\mathrm{mm})$ & \\
& 7 DAI & $14 \mathrm{DAI}$ & $21 \mathrm{DAI}$ \\
\hline $\mathrm{Cb} 0$ & $98.27 \mathrm{bc}$ & $111.77 \mathrm{~b}$ & $116.73 \mathrm{~b}$ \\
$\mathrm{Cb} 1$ & $43.20 \mathrm{a}$ & $77.27 \mathrm{a}$ & $81.90 \mathrm{a}$ \\
$\mathrm{Cb} 2$ & $24.40 \mathrm{a}$ & $63.33 \mathrm{a}$ & $65.13 \mathrm{a}$ \\
$\mathrm{Cb3}$ & $44.03 \mathrm{a}$ & $51.73 \mathrm{a}$ & $53.03 \mathrm{a}$ \\
PAb0 & $141.27 \mathrm{e}$ & $204.87 \mathrm{e}$ & $210.00 \mathrm{de}$ \\
PAb1 & $114.27 \mathrm{~cd}$ & $184.03 \mathrm{de}$ & $204.57 \mathrm{de}$ \\
PAb2 & $86.57 \mathrm{~b}$ & $153.70 \mathrm{~cd}$ & $169.90 \mathrm{c}$ \\
PAb3 & $91.00 \mathrm{bc}$ & $118.20 \mathrm{~b}$ & $168.70 \mathrm{c}$ \\
KP2b0 & $100.77 \mathrm{bc}$ & $200.83 \mathrm{e}$ & $170.37 \mathrm{c}$ \\
KP2b1 & $137.00 \mathrm{de}$ & $177.20 \mathrm{cde}$ & $232.50 \mathrm{e}$ \\
KP2b2 & $107.57 \mathrm{bc}$ & $152.3 \mathrm{c}$ & $192.00 \mathrm{~cd}$ \\
KP2b3 & $104.47 \mathrm{bc}$ & $168.70 \mathrm{c}$ \\
\hline
\end{tabular}

Different letters over bar of indicates significant difference in treatment according to Tukey's multiple range test $\mathrm{p} \leq 0.01), \mathrm{C}$ (control), PA isolates, KP2 isolates, b0 $\left(0 \mathrm{dsm}^{-1}\right), \mathrm{b} 1\left(4 \mathrm{dSm}^{-1}\right), \mathrm{b} 2$ $\left(8 \mathrm{dSm}^{-1}\right), \mathrm{b} 3\left(12 \mathrm{dSm}^{-1}\right)$

Table 3 showed that plant height growth inoculated with KP2 isolates at salinity level $4 \mathrm{dSm}^{-1}$ has significantly higher compared with control at non-saline condition. This result showed that, inoculation $\mathrm{N}_{2}$-fixing rhizobacteria could improve root growth significantly at from 7 to 21 DAI in $4 \mathrm{dSm}^{-1}$ salinity level. At 7 and 14 DAI KP2 isolate at $4 \mathrm{dSm}^{-1}$ salinity has no significant different with PA isolates at $4 \mathrm{dSm}^{-1}$ salinity with plant height $137.00 \mathrm{~mm}$ and $141.27 \mathrm{~mm}$ respectively at $7 \mathrm{DAI}$ and 200.83 and $204.87 \mathrm{~mm}$ at $14 \mathrm{DAI}$. Then, at $21 \mathrm{DAI} \mathrm{KP} 2$ at $4 \mathrm{dSm}^{-1}$ salinity has higher value even though not significantly different compared to PA both at $0 \mathrm{dSm}^{-1}$ and $4 \mathrm{dSm}^{-1}$ salinity level. This indicated that giving isolates to rice plants can increase water efficiency, photosynthesis, and stomatal opening [27]. Therefore, after 21 DAI KP2 at $4 \mathrm{dSm}^{-1}$ has the best plant height compared to control booth with same salinity and with non-saline conditions. Plant height inoculated with $\mathrm{KP} 2$ at $8 \mathrm{dSm}^{-1}$ lower compared to $\mathrm{KP} 2$ at $4 \mathrm{dSm}^{-1}$ which indicated there was a decrease which indicated that the salinity level had exceeded the salinity tolerance limit, resulting in a decrease in microbial performance in supporting plant growth [28]. This is because salinity is a factor that inhibits the nitrification process so that it can reduce the carrying capacity of bacteria to plants [29]. Plant height parameter have a positive 
effect on plant resistance to inundation conditions (generally occurs in saline rice field ecosystems on tidal land) because it causes the leaf surface to be on the water surface and can get sunlight and $\mathrm{CO}_{2}$ (photosynthesis), as well as $\mathrm{O}_{2}$ for respiration, especially maintaining oxygen supply on plant roots through aerenchyma [30]. This is following the research of Shamin which stated that from 35 colonies there were only five Azotobacter isolates that were tolerant to $6 \%$ $\mathrm{NaCl}$ and 2 isolates tolerant to $10 \% \mathrm{NaCl}$ [28].

\subsubsection{Effect $\mathbf{N}_{2}$-Fixing Rhizobacteria on Leave Number}

Observation of the number of leaves per plant used in rice bioassays was carried out every 7-21 DAI. This observation was aimed to determine one of the growth components of Inpari Unsoed 79 rice plant showed at Table 4 .

Table 4: Effect of $\mathrm{N}_{2}$-fixing rizobacteria on Inpari rice leave number 7-21 DAI at various salinity

\begin{tabular}{|llll|}
\hline Treatment & $\begin{array}{l}\text { Leave number } \\
\text { 7 DAI }\end{array}$ & $14 \mathrm{DAI}$ & $21 \mathrm{DAI}$ \\
\hline $\mathrm{Cb} 0$ & 2.33 & $3.00 \mathrm{bc}$ & 3.00 \\
$\mathrm{Cb} 1$ & 1.67 & $2.00 \mathrm{a}$ & 3.33 \\
$\mathrm{Cb} 2$ & 1.67 & $2.00 \mathrm{a}$ & 2.00 \\
$\mathrm{Cb} 3$ & 1.00 & $2.33 \mathrm{ab}$ & 2.67 \\
$\mathrm{PAb0}$ & 2.00 & $3.00 \mathrm{bc}$ & 4.00 \\
$\mathrm{PAb1}$ & 2.00 & $3.00 \mathrm{bc}$ & 3.67 \\
PAb2 & 2.00 & $3.00 \mathrm{bc}$ & 3.67 \\
PAb3 & 2.00 & $3.00 \mathrm{bc}$ & 3.00 \\
KP2b0 & $3.33 \mathrm{c}$ & 3.33 \\
KP2b1 & 2.67 & $3.00 \mathrm{bc}$ & 3.33 \\
KP2b2 & 2.33 & $3.00 \mathrm{bc}$ & 4.00 \\
KP2b3 & 2.00 & $3.00 \mathrm{bc}$ & 3.33 \\
\hline
\end{tabular}

Different letters over bar of indicates significant difference in treatment according to Tukey's multiple range test $\mathrm{p} \leq 0.01), \mathrm{C}$ (control), PA isolates, $\mathrm{KP} 2$ isolates, $\mathrm{b} 0\left(0 \mathrm{dsm}^{-1}\right), \mathrm{b} 1\left(4 \mathrm{dSm}^{-1}\right), \mathrm{b} 2$ $\left(8 \mathrm{dSm}^{-1}\right), \mathrm{b} 3\left(12 \mathrm{dSm}^{-1}\right)$

Table 4 showed the number of leaves at 7- 21 days after inoculation (DAI). At 7 DAI there is no significant effect $\mathrm{N}_{2}$-fixing rhizobacteria on leave number improvement ant Inpari rice plant. But there was tendency that KP2 at non saline condition gave better growth with mean leave number 2.67, then at 14 DAI KP2 at non-saline condition gave highest leave number, but there was no significant different at 4, 8 , and $12 \mathrm{dSm}^{-1}$ salinity level. Then, at $21 \mathrm{DAI}$ generally there was no significant effect of treatment to leave number production. This is showed that salinity is a stress salinity is the main limiting factor for plant growth [31]. Also, salinity stress affects plant health by reducing phosphorus availability, inducing osmotic stress, triggering ethylene production, mediating $\mathrm{Na}^{+}$and $\mathrm{Cl}^{-}$toxicity, and causing reactive oxygen species (ROS) that inhibit plant growth [32]-[34]. 
Vol. 07, No. 01; 2022

ISSN: $2456-8643$

\section{CONCLUSION}

The research conclude that all isolate could grow and tolerate salinity stress up to $12 \mathrm{dSm}^{-1}$ and growth faster under salinity stress after 48 hours from inoculation. PA isolates grew $42.92 \%$ faster while KP2 was $57.80 \%$ both at $12 \mathrm{dSm}^{-1}$ compared to control. The result also showed that $\mathrm{KP} 2$ isolates give the best performance at $4 \mathrm{dSm}^{-1}$ significantly increasing plant height $50.45 \%$, plant height $183.88 \%$ compare to without inoculation on the same level salinity. Therefore, that ideal salinity for KP2 isolates to improve rice seedling growth under salinity stress was $4 \mathrm{dSm}^{-1}$.

\section{Acknowledgement}

This paper and research behind it would not have been possible without exceptional support of my supervisior, Prof. Dr. Ir . Tualar Simarmata, MS., and Prof. Dr. Ir. Reginawanti Hindersah MP., also Dr. Ir. Mieke Rochimi Setiawati, MP. Their enthusiasm, knowledge and exacting attention to detail have been an inspiration and kept my work on track from first draft to final draft of this paper. The writer also said many thanks to ALG (Academic Leadership Grant) for financial support for this research.

\section{REFERENCES}

[1] Central Bureau of Statistics indonesia, "Harvest Area, Production, and Rice Productivity by Province," Jakarta, 2020.

[2] N. Nafisah, A. Hairmansis, and T. Sitaresmi, "Grain Yield of Rice Elite Lines Under Saline Prone Condition in Cilamaya Wetan, Karawang Subdistrict West Java," J. Suboptimal Lands, vol. 6, no. 1, pp. 21-32, 2017.

[3] M. Alwi, "Prospect of Tidal Swamp Land for Rice Plants," in Proceedings of the National Seminar on Location-Specific Agricultural Technology Innovation, 2014, no. 2007, pp. 45-59.

[4] N. M. Kusrachdiyanti, F. H. Khumairah, R. Hindersah, and T. Simarmata, "Isolatic Rhizobactery and Isolative Nitrogen Testing as Growth Extractor at Saline Soils Ecosystems," J. Ilm. Pertan., vol. 16, no. 2, pp. 116-125, 2020.

[5] H. H. Zahran, M. S. Ahmad, and E. A. Afkar, "Isolation and characterization of nitrogen-fixing moderate halophilic bacteria from saline soils of Egypt," J. Basic Microbiol., vol. 35, no. 4, pp. 269-275, 1995, doi: 10.1002/jobm.3620350412.

[6] P. Suprayogi, J. Salsabila, S. Purwanto, J. Salsabila, P. Suprayogi, and J. Salsabila, "Growth Response and Yield of Saline Tolerant Rice Varieties to Bio-fertilizer Application at Central Java North Coastal Saline Paddy Field," IOP Conf. Ser. Earth Environ. Sci., vol. 406, no. 1, pp. 1-5, 2019, doi: 10.1088/1755-1315/406/1/012001.

[7] S. R. Grattan, M. C. Shannon, and S. R. Roberts, "Rice is More Sensitive to Salinity than previously thought," Calif. Agric., vol. 56, no. 6, pp. 189-195, 2002.

[8] R. Salwan, A. Sharma, and V. Sharma, "Microbes mediated plant stress tolerance in saline agricultural ecosystem," Plant Soil, vol. 442, no. 1-2, pp. 1-22, 2019, doi: 10.1007/s11104-019-04202-x.

[9] W. Wang, B. Vinocur, and A. Altman, "Plant responses to drought, salinity and extreme temperatures: Towards genetic engineering for stress tolerance," Planta, vol. 218, no. 1, pp. 1-14, 2003, doi: 10.1007/s00425-003-1105-5.

[10] V. Kumar, R. Prasad, M. Kumar, and D. K. Choudhary, Microbiome in Plant Health and 
Disease: Challenges and Opportunities, 1st ed. singapore: Springer Nature Singapore, 2019.

[11] Z.-C. Wang and G. D. Watt, "Large anions induce H2-production from the nitrogenase MoFe proteins of Clostridium Pasteurianum and Azotobacter vinelandii," Mater. Des., pp. 1-36, 2018, doi: 10.1016/j.matdes.2019.108334.

[12] S. Szymańska, G. B. Dąbrowska, J. Tyburski, K. Niedojadło, A. Piernik, and K. Hrynkiewicz, "Boosting the Brassica napus L. tolerance to salinity by the halotolerant strain Pseudomonas stutzeri ISE12," Environ. Exp. Bot., vol. 163, no. March, pp. 55-68, 2019, doi: 10.1016/j.envexpbot.2019.04.007.

[13] S. H. Habib, H. Kausar, H. M. Saud, M. R. Ismail, and R. Othman, "Molecular characterization of stress tolerant plant growth promoting rhizobacteria (PGPR) for growth enhancement of rice," Int. J. Agric. Biol., vol. 18, no. 1, pp. 184-191, 2016, doi: 10.17957/IJAB/15.0094.

[14] R. Catoira et al., "Four genes of Medicago truncatula controlling components of a Nod factor transduction pathway," Plant Cell, vol. 12, no. 9, pp. 1647-1665, 2000, doi: 10.1105/tpc.12.9.1647.

[15] R. M. Atlas, Handbook ofMicrobiological Media Fourth Edition, 4th ed. Wahington D.C: CRC Press, 2010.

[16] R. Hindersah, P. Suryatmana, M. R. Setiawati, B. N. Fitriatin, A. Nurbaity, and T. SImarmata, "Salinity Resistance of Azotobacter Isolated from Saline Soil in West Java," in Plant Growth Promoting Rhizobacteria: Potential microbes for sustainable agriculture, no. 25, S. Antonius, Ed. Springer Singapore, 2019, pp. 323-335.

[17] B. Suprihatno et al., Description of rice varieties. 2009.

[18] Cutrisni, F. C. Suwarno, and Suwarno, "Testing Seed Storability with Physical Rapid Aging Method and Vigor on Rice Genotypes," Bul. Agrohorti, vol. 3, no. 3, pp. 366-376, 2015, doi: 10.1017/CBO9781107415324.004.

[19] A. Kumar, S. Singh, A. K. Gaurav, S. Srivastava, and J. P. Verma, "Plant GrowthPromoting Bacteria: Biological Tools for the Mitigation of Salinity Stress in Plants," Front. Microbiol., vol. 11, pp. 1-41, 2020, doi: 10.3389/fmicb.2020.01216.

[20] D. R. Polonenko, C. I. Mayfield, and E. B. Dumbroff, "Microbial responses to saltinduced osmotic stress V . Effects of salinity on growth and displacement of soil bacteria Introduction High levels o $\mathrm{f}$ salts in agricultural soils can result from adverse environmental conditions or from man 's manipulation o," Plant Soil, vol. 92, pp. 417425, 1986.

[21] R. A. James, C. Blake, C. S. Byrt, and R. Munns, "Major genes for $\mathrm{Na}+$ exclusion, Nax1 and $\mathrm{Nax} 2$ (wheat HKT1;4 and HKT1;5), decrease $\mathrm{Na}+$ accumulation in bread wheat leaves under saline and waterlogged conditions," J. Exp. Bot., vol. 62, no. 8, pp. 29392947, 2011, doi: 10.1093/jxb/err003.

[22] A. Rahnama, R. A. James, K. Poustini, and R. Munns, "Stomatal conductance as a screen for osmotic stress tolerance in durum wheat growing in saline soil," Funct. Plant Biol., vol. 37, no. 3, pp. 255-263, 2010, doi: 10.1071/FP09148.

[23] R. Munns, "Genes and Salt Tolerance," New Phytol., vol. 167, no. 3, pp. 645-663, 2005.

[24] J. Rozema and T. Flowers, "Crops for a Salinized World," Science (80-. )., vol. 322, no. 5907, pp. 1478-1480, 2008. 
[25] B. Gupta and B. Huang, "Mechanism of Salinity Tolerance in Plants: Physiological, Biochemical, and Molecular Characterization," Int. J. Genomics, pp. 1-19, 2014.

[26] R. Munns and M. Tester, "Mechanisms of salinity tolerance," Annu. Rev. Plant Biol., vol. 59, pp. 651-681, 2008, doi: 10.1146/annurev.arplant.59.032607.092911.

[27] S. Ranjan, S. Sow, S. R. Choudhury, S. Kumar, and M. Ghosh, "Biofertilizer as a Novel Tool for Enhancing Soil Fertility and Crop Productivity: A Review," Int. J. Curr. Microbiol. Appl. Sci., no. 11, pp. 653-665, 2020.

[28] A. Shamim, J. H. Sheikh, A. H. SK, and K. D. Rakesh, "Isolation and Characterization of Salinity Tolerant Azotobacter sp," Greener J. Biol. Sci., vol. 2, no. 3, pp. 043-051, 2012, doi: $10.15580 / g j b s .2012 .3 .110312207$.

[29] J. Li et al., "System performance and microbial community succession in a partial nitrification biofilm reactor in response to salinity stress," Bioresour. Technol., vol. 270, pp. 512-518, 2018, doi: 10.1016/j.biortech.2018.09.068.

[30] Sujinah, N. Agustiani, and I. A. Rumanti, "Adaptability of Rice in Stagnant Flooding," Penelit. Pertan. Tanam. Pangan, vol. 4, no. 1, pp. 17-26, 2020.

[31] R. Mittler, "Abiotic stress, the field environment and stress combination," Trends Plant Sci., vol. 11, no. 1, pp. 15-19, 2006, doi: 10.1016/j.tplants.2005.11.002.

[32] R. K. Sairam and A. Tyagi, "Physiology and molecular biology of salinity stress tolerance in plants," Curr. Sci., vol. 86, no. 3, pp. 407-421, 2004.

[33] S. M. Nadeem, M. Ahmad, Z. A. Zahir, A. Javaid, and M. Ashraf, "The role of mycorrhizae and plant growth promoting rhizobacteria (PGPR) in improving crop productivity under stressful environments," Biotechnol. Adv., vol. 32, no. 2, pp. 429-448, 2014, doi: 10.1016/j.biotechadv.2013.12.005.

[34] D. Egamberdieva, G. Berg, K. Lindström, and L. A. Räsänen, "Alleviation of salt stress of symbiotic Galega officinalis L. (goat's rue) by co-inoculation of Rhizobium with rootcolonizing Pseudomonas," Plant Soil, vol. 369, no. 1-2, pp. 453-465, 2013, doi: 10.1007/s11104-013-1586-3. 